\title{
Internally displaced persons and COVID-19: a wake-up call for and African solutions to African problems - the case of Zimbabwe
}

\author{
Roda Madziva, Juliet Thondhlana, Evelyn Chiyevo Garwe, \\ Moses Murandu, Godfrey Chagwiza, Marck Chikanza \\ and Julita Maradzika
}

Abstract: In this paper we engage with the situation of internally displaced persons (IDPs) residing in two informal settlements in Zimbabwe, within the context of the COVID-19 pandemic. We draw on an ongoing collaborative, interdisciplinary, and impact-oriented project that seeks to help IDPs to be better prepared to protect themselves from the COVID-19 pandemic. We start by providing an analysis of the existing COVID-19 preventative messages and their applicability to the IDPs' situation, and further argue for the need to adopt Transformative Public Health Education (TPHE), to allow co-creation and co-production with IDPs in order to produce messages and interventions that suit their lived realities. We then move on to show the importance of leveraging local low-cost COVID-19 solutions, drawing on the example of the innovations that the project adapted in order to meet the needs of the IDPs residing in the two informal settlements.

Keywords: Internally Displaced Persons, COVID-19 pandemic, Zimbabwe, informal settlements, innovations.

(C) The author(s) 2021. This is an open access article licensed under a Creative Commons Attribution-NonCommercial-NoDerivs 4.0 Unported License 


\section{Introduction}

The novel Coronavirus disease 19 (COVID-19), caused by severe acute respiratory syndrome Coronavirus-12 (SARS-CoV-2), has been at the centre of a worldwide panic and global health concern since December 2019. Indeed, the World Health Organization officially declared COVID-19 a global pandemic on 11 March 2020 (WHO 2020a). The pandemic has seen healthcare systems in even the most advanced countries being overwhelmed. However, despite the fact that COVID-19 is a global pandemic, each context has experienced the crisis differently.

Zimbabwe, like many other African countries, recorded low numbers of COVID-19 in the first phase, but has seen a spike in an ongoing second phase. The country experienced over 1,000 deaths in the month of January 2021, including four cabinet ministers and several high-ranking politicians and professionals. There are fears that the new SARS-CoV-2 variant (501Y. V2), which was discovered in South Africa in November 2020 and has already been detected in other Southern African countries, such as Botswana and Zambia (Makoni 2021), could have been transported into Zimbabwe over the Christmas festival period when thousands of Zimbabweans living in South Africa returned home (Chakamba 2021). This is very concerning given that Zimbabwe's health system was already overstretched before the COVID-19 epidemic. Way before the pandemic, several hospitals did not have adequate equipment, running water, electricity, or medicines (Kidia 2018). With the arrival of the pandemic, the first death from COVID-19 involved a young man who was from a wealthy family, but could not be put on a ventilator due to unavailability of resources such as electricity and connection cables (Daniels 2020). At the same time, persistent strikes by health workers have also worsened the situation, especially for low-income households who cannot afford private hospital charges.

The second wave of the pandemic, and particularly the alarming death rates it has brought, especially among political figures, comes as a wake-up call for Zimbabwe, which has just joined the world in the race to acquire vaccines. Indeed, as the COVID19 virus takes its toll, non-pharmacological preventive measures, such as social distancing (to reduce contact), hygiene practices (such as regular washing of hands using soap), and the use of sanitisers and protective clothing such as masks, have become more critical to mitigating the impact of the pandemic on societies, the health system, and the economy. To complement these, the government has put in place some tight lockdown measures, including a curfew from 6am to 6pm (except for essential services).

Speaking at the burial of two cabinet ministers, who were buried in a single ceremony, the Zimbabwe Vice-President Constantino Chiwenga lamented that COVID-19 'does not discriminate between the powerful and the weak, the privileged 
and the deprived, the haves and the have-nots. It is a ruthless juggernaut that leaves a trail of despair and desperation' (Mutsaka 2021).

While it is true that the COVID-19 virus 'does not discriminate between the powerful and the weak, the privileged and the deprived, the haves and the have-nots', we argue that internally displaced persons (IDPs) are a population which, due to various factors, is extremely vulnerable to the spread of the COVID-19 virus. These factors include population density, as IDPs live in cramped conditions in informal settlements. These are spaces which make it extremely difficult (if not impossible) to exercise the recommended social distancing measures (Refugees International 2020, UNHCR 2020a). Most crucially, displaced people generally lack access to even primary healthcare services. What this therefore means is that, for this population, 'intensive care - the kind of care that COVID-19 patients need when they develop acute respiratory distress syndrome - is scarce to non-existent, especially in camp settings' (Refugees International 2020). This is further made more complex by the fact that displacement in itself often leads to serious health conditions, such as malnutrition, psychosocial stress, and other infectious diseases, such as tuberculosis, and these are health conditions known to be risk factors for COVID-19 infection and mortality (Refugees International 2020).

Focusing on the situation of IDPs in Zimbabwe, this article argues for the need to leverage local low-cost COVID-19 solutions in informal settlements, to protect and address the contextual needs of IDPs. We see this as an important approach to undertake, in a context where the global COVID-19 pandemic is threatening to limit the capacity of the developed world to support developing countries, and therefore resonates with the mantra 'African solutions to African problems'.

The article will proceed as follows. Section 1 provides the background to IDPs in Zimbabwe. Section 2 offers a discussion of the study on which this paper is based. Section 3 provides an analysis of the existing COVID-19 preventative messages and their applicability to the IDPs situation, and further argues the case for a Transformative Public Health Education (TPHE), and the need to rethink some of the current and generic COVID-19 messages to suit IDPs' local realities. Section 4 discusses the importance of leveraging local low-cost COVID-19 solutions, drawing on the example of the innovations that the project is currently adapting in order to meet the needs of IDPs residing in informal settlements. Last is the conclusion.

\section{IDPs in Zimbabwe}

The United Nations Guiding Principles on Internal Displacement (GPID) define the internally displaced: 
as persons or groups of persons who have been forced or obliged to flee or to leave their homes or places of habitual residence, in particular as a result of or in order to avoid the effects of armed conflict, situations of generalized violence, violations of human rights or natural or human-made disasters, and who have not crossed an internationally recognised state border. (Deng 1999: 6)

While internal displacement is a significant feature in the Zimbabwean context, the number of those who are internally displaced is not fully known. UNHCR (2011) estimates it to range from 80,000 to 1 million. While Zimbabwe has ratified both the UN Guiding Principles on Internal Displacement and the 2009 Kampala Convention for the Protection and Assistance of IDPs in Africa, the adoption and practical implementation of these instruments in domestic law are issues of grave concern. More generally, both the causes of disruptions and the constraints on the implementation of humanitarian programmes can be attributed to Zimbabwe's challenging economic and political environment (Hartnack 2005). To this end, academics have argued that the Zimbabwean IDP phenomenon is 'highly complex' (Rodgers 2006) as it is a result of a wide spectrum of events, which range from 'disastrous government policies [to] a few isolated weather related displacements' (Naidu \& Benhura 2014: 153).

Most crucially, the IDPs themselves have complex and intersectional identities, which makes it difficult for some of them to claim their human rights. Notably, most IDPs are people of foreign origin (mostly Malawian, Zambian, or Mozambique) who are naturalised descendants of farmworking migrants/refugees, who became displaced as a result of Zimbabwe's controversial land reform (between 2002 and 2004) programme and the subsequent 2007 government cleaning-up exercise operation, dubbed 'operation murambatsvina' (Hager 2007, Hammar 2008). This echoes the assertion by Juss (2013: 263) that 'displacements that occur due to man-made ... actions are more prevalent than those caused by natural disasters'. Meanwhile, due to their migrant background, most IDPs ordinarily do not have access to a rural home; hence they reside in informal settlements. As Hartnack (2005: 173) argues,

Despite the fact that ... most of the [former] farm workers are Zimbabwean-born, they are still perceived, especially in nationalist discourses, as 'foreigners' who are not deserving of the same rights and entitlements as other citizens of Zimbabwe. In the land reform programme, they have been largely ignored as beneficiaries.

In their research with IDPs residing in two informal settlements-Mandebvu and Epworth (both close to the capital city Harare) - Madziva and Chikanza (2019) have shown that both settlements (like many other settlements; see Hammar 2008, Naidu \& Benhura 2014) exhibit signs of socio-economic deprivation, as characterised by muddy structures, housing an average family of four per room. In the context of COVID-19, such structures are highly contagious as they lack critical facilities for 
practising the pandemic standard of hygiene. In other words, due to their social and economic deprivation, IDPs in Zimbabwe undeniably have needs that are distinct, which not only require special attention, but may lead to poor outcomes in health, especially in the context of the COVID-19 pandemic if no urgent action is taken. This further means that, because of long-existing inequalities, IDPs are more likely to feel the consequences of the pandemic both in the short and long term. Thus, as UNHCR (2020b: 2b) argues, IDPs 'may face risks which are specific to their displacement in the context of COVID-19'. The IDPs' situation in Zimbabwe thus calls for an urgent and well-coordinated timely and effective public health response.

\section{The study and methodology}

This article is based on data collected for the project, 'Internally Displaced Persons and COVID-19: Leveraging local low cost COVID-19 solutions in informal settlements in Zimbabwe'. This is an impact-oriented project which brings together an interdisciplinary team from three Zimbabwean universities, two UK universities, and a local NGO, focusing on IDPs who reside in two informal settlements, Mandebvu and Epworth. Mandebvu, located $19 \mathrm{~km}$ west of Harare city centre, is situated at a former farm, now deserted following the controversial land reform programme. Epworth is a peri-urban and semi-formal settlement, about $20 \mathrm{~km}$ east of the city centre. A cross-sectional study was carried out in the two identified study communities. Participants were selected using random and purposive techniques. The inclusion criterion was any adult who had lived in the communities for at least six months prior to the study. The sample included both adult males $(35.49 \%)$ and females $(64.51 \%)$ who were abled or disabled. Our primary sampling unit was a household, and the head of the household was interviewed. Gender balance was achieved by systematically alternating respondents between households. COVID-19 Rapid Needs Assessment (RNA) questionnaires were used to collect data from the selected participants.

The sample size was calculated using the formula:

$$
n=\frac{z^{2} r(1-r)[1+\rho(m-1)] k}{e^{2}}
$$

where $n$ is the sample size in terms of number of participants to be selected, $z$ is standardised $z$-score (normal variate) corresponding to a $95 \%$ confidence interval. The estimate of the indicator of interest to be measured by the survey is denoted by $r$ and is taken to be 0.6 using the DHS suggested prevalence rate so as to achieve a minimum margin of error, and the intra-cluster correlation coefficient of $\rho=0.45$ was selected using knowledge of the characteristics of the infrastructure. The number of 
households to be selected per study area, $m$. The factor accounting for non-response, $k$, was calculated to be 1.1, considering that in developing countries the non-response rate is typically $10 \%$ or less. The margin of error, $e$, is taken to be 0.030 ( $97 \%$ confidence). Using these values, the sample size is 600 participants. This sample size was adequate to achieve the objectives of this study. The sample was drawn from Epworth with a population of 226,671 and Mandebvu with a population of approximately 30,000 (ZIMSTAT 2017).

Due to the nature of the disease and the need for safeguarding both the researcher and the research subjects, protective masks and sanitisers were given to respondents before the interview, and World Health Organization guidelines (WHO 2020b) including social distancing were observed. Furthermore, COVID-19 Rapid Needs Assessment (RNA) questionnaires were used and administered using tablets riding on the KoBo Collect platform, and no papers were exchanged. Questions focused on: COVID-19 knowledge and safety and preventive measures; economic situation; existing skills; health and care needs (older people, women, children, etc); caring practices; support networks and community solidarity.

Data was directly captured and stored on portable devices (which were encrypted and anonymised) while in the field. After the data had been anonymised and redacted(and translated from Shona to English) a copy of the data was submitted to institutional data repositories and other platforms of partner institutions following the same guidelines.

Primary data analysis was done in KoBo. Further analysis was done in SPSS, to allow for further probing and tests for association.

\section{COVID-19 preventive messages and their accessibility for IDPs}

It has long been established that information is power (Black 2014) - it can be used effectively or abused, and at times it may fail to reach some sectors of society, especially the most vulnerable (Hutchins et al. 2009). In times of global health pandemics such as COVID-19, proper management of information (collection or dissemination) is critical for it to achieve the intended purpose.

The Zimbabwe Ministry of Health in partnership with local and international organisations (for example, UNICEF) have made information on COVID-19 abundantly available to the bulk of its populace, which is disseminated through diverse channels, including print and electronic media, community engagement and mobile outreach vans. The government's intention is to penetrate even hard-to-reach communities using a multi-sectoral approach for the public health education process. 
Certainly, communication is essential in providing information to the public, as this helps to increase preparedness to fight the COVID-19 pandemic. To this end, the Ministry of Health and Child Care (MOHCC) has developed a Risk Communication and Community Engagement Preparedness, Readiness Response Plan to COVID-19 (February 2020). The plan has identified stakeholders at high risk of COVID-19, which include: people moving across borders; people working at ports of entry (POE); business persons engaged in cross-border trading; workers in health care settings, including traditional healers; personnel in pharmacies; persons with underlying medical conditions, their family members, and immediate contacts. Missing are IDPs, which raises the question of whether the messages that IDPs are receiving are appropriate for them.

We conducted a survey in which we solicited information about IDPs' level of knowledge, responsiveness to the COVID-19 pandemic, their perceptions and skills about the pandemic, and how they could best be supported to protect themselves. The study also assessed how the community could be involved in the design of tailored COVID-19 responses.

We also conducted a COVID-19 information desk review to complement the findings from our survey, for the purpose of assessing the best intervention for our population, and whether the gaps in their needs were being met. Emerging findings indicate that the current information and preventive measures may not be appropriate or even readily accessible for our IDP population residing in informal settlements, as these are largely not targeted to their specific needs.

Below we look at the key information disseminated and discuss how effective each of these messages are in the context of IDPs in Zimbabwe.

(i) Stay at home. Assuming that all is provided for, the message to stay at home would presumably be welcomed by many as a form of taking a break from outdoor activities or a holiday from formal work. Given that such messages are not accompanied by any supportive infrastructure to meet people's day-to-day basic needs, such an approach could be viewed by IDPs as a 'privilege' only for the rich, and not for the rank and file characterised mostly by self-employed people who have to work on a day-to-day basis to put food on the table. As our research has shown, participants acknowledged being aware of the need to observe movement restrictions as a measure to curb the spread of infection. However, almost all participants noted that they earn below US\$50 per month and, as a result, they 'cannot practice what is preached' (Mackworth-Young et al. 2020) as 'hustling' is the order of the day. Hustling refers to 'making a living' or 'making do' with what is available, and is often a response to economic and life austerities (Thieme 2018). This means that the stay-home message, without any 'cushionary' measures to ensure reliable access to long-term food supplies, 
is inappropriate to the IDP population, for whom money and food are scarce commodities only available to those who toil on a daily basis.

(ii) Sociallphysical distancing and the use of personal protective equipment (PPE). IDPs live in overcrowded environments that make it impossible to practise social distancing. As our research findings show, it is common to see three or four families living in one household, and/or six family members sharing one room (also see Madziva \& Chikanza 2019). In addition, these communities share ablutions, water points, and other common facilities. Without individual toilets, piped water, and household-specific amenities, the inconsistencies between adhering to the pronounced social distancing regulations and the primacy of survival are not surprising (Glassman et al. 2020). Of particular concern, as our research further shows, is that almost half of the participants reported having pre-existing conditions, including respiratory problems, heart problems, gastro-intestinal, diabetes, joint aches and pains, and hypertension, and these are some of the health conditions known to be risk factors for COVID-19 infection and mortality. Indeed, our findings have confirmed that IDP settlements are crowded, thereby making social distancing a challenge, and poorly resourced with limited water sources, which make it difficult for this population to practise good hygiene. Also, as already noted, the informal settlement residents are people who live in abject poverty, making it difficult for them to provide the necessary basic PPE, such as face masks for their households.

(iii) Wash hands frequently with soap and water or use hand sanitisers. The use of alcohol-based sanitisers or washing hands with soap and running water are the recommended ways of protecting oneself and others against the virus. However, IDPs have no access to clean water let alone tap water, and frequently lack money to purchase soap and other disinfectants. Thus, families struggle to ensure that they always have water and soap to enable them to wash their hands frequently.

The foregoing shows tensions that exist between the COVID-19 prevention regulations and other pressing human needs, with IDPs being forced to prioritise securing basics such as income, food, and water over compliance to COVID-19 regulations. This predisposes the IDP communities to a further spreading of the virus, and calls for urgent appropriate solutions using locally available cost-effective interventions to enable IDPs to protect themselves from potential viral exposure (see section 4).

\section{Language and mode of delivery}

Our research has also shown that the ways in which messages are packaged and the language used are not always accessible to IDPs, most of whom have low levels of education and would prefer to have some of these messages packaged in their own 
different languages, as well as the use of visual aids such as images to illustrate how particular procedures could best be carried out. In terms of delivery, our IDPs have noted that they would prefer the use of radio and community-based approaches, among other things.

Below we make a case for context-based health education approaches as opposed to heavy-handed top-down approaches that are largely insensitive to vulnerable people's lived realities. We argue that a Transformative Public Health Education (TPHE) approach is essential when working with vulnerable populations, in order to provide appropriate information and use delivery modes deemed appropriate by the communities themselves.

\section{The need for a Transformative Public Health Education (TPHE)}

In order to prevent a COVID-19 catastrophe in IDP communities, it is critical to move away from sending out generic messages to providing them with targeted information, through co-production and co-creation.

Here we propose a TPHE, premised on the recognition that IDPs possess the 'lived' experience, knowledge, and survival skills that need to be nurtured, in order to ensure success and applicability of COVID-19 interventions to support community transformation (see Facer et al. 2020). Taking this approach not only helps to ensure the inclusion of IDPs in the local COVID-19 health legislative policies, but is also in line with the United Nations recommendations. Indeed, the UN Special Rapporteur on the human rights of internally displaced persons, Cecilia Jimenez-Damary, issued a public statement on 1 April 2020, urging governments to 'step-up their measures' to protect IDPs worldwide from the COVID-19 threat. She went further to emphasise the need for governments to include IDPs in their COVID-19 decision-making process. As Jimenez-Damary argues, 'Internally displaced persons know best the specific challenges they face. Their participation in identifying these challenges and designing tailored responses to COVID-19 is essential' (UNHCR 2020c).

Given the findings we have presented above, we have worked with IDPs to package the public health messages in a more targeted way to suit their specific needs. Specifically, we included the IDPs community in re-designing the key messages, packaging them in local language(s), and making them context specific, relevant, and age appropriate (Facer et al. 2020). We also took into consideration their preferred channels of communication, including radio and community-based information booths, using different illustrations and images to ensure that the messages are easily accessible. IDP community health promoters (VHPs) were trained to promote health information within the informal settlements, following adaption of the MOHCC's COVID-19 material to make the information context-appropriate.. 
We believe that through capacity-building, IDPs' knowledge about COVID-19 will help transform the way in which they view themselves, and inspire them to participate in COVID-19 prevention and responses.

\section{Adaption of local low cost COVID-19 innovations}

Vieira et al. (2020) observe that, as the pandemic reaches low- and middle-income countries characterised by weaker health systems and limited resources, the lower socio-economic status of especially vulnerable populations may make implementing the preventive measures more challenging. Given the challenges that IDPs face, especially in relation to staying home and social distancing as noted above, we decided to adapt some of the low-cost innovations developed by one of the project partners, Zimbabwe Ezekiel Guti University (ZEGU). Through its innovation hub, ZEGU has developed a number of innovations that were introduced in Zimbabwe as an immediate solution to help health facilities curb the spread of COVID-19. The project has adapted the following innovations to help IDP communities be more prepared to protect themselves from the COVID-19 pandemic.

\section{Low-cost full-body sanitisation booths}

We have adapted a full-body sanitising booth (see Figure 1), made of an aluminum structure with plastic, plexiglass, or tempered glass wall cladding. The full-body sanitising booths were placed at entrances to informal settlements (one at each informal settlement) to allow the IDP population to sanitise themselves as they leave and/or come back into the settlement. The full-body sanitising booth has sensors that detect the presence of a person and automatically release sanitiser. Before a person enters the booth, their temperature is automatically captured and displayed for the person to read.

\section{Sanitisation dispensers and footbath pans}

We installed a combined handwashing station, footbath, and manual sanitiser dispenser (see Figure 2), at sites in the informal settlements where IDPs frequently gather to fetch water. The manual hand-sanitiser dispenser was made of cheap and readily available material, in this case an empty cooking oil plastic container, connected to a string which is then attached to a foot pedal made of wood. The dispensers are operated using the foot to dispense liquid hand sanitiser. IDPs are encouraged to 


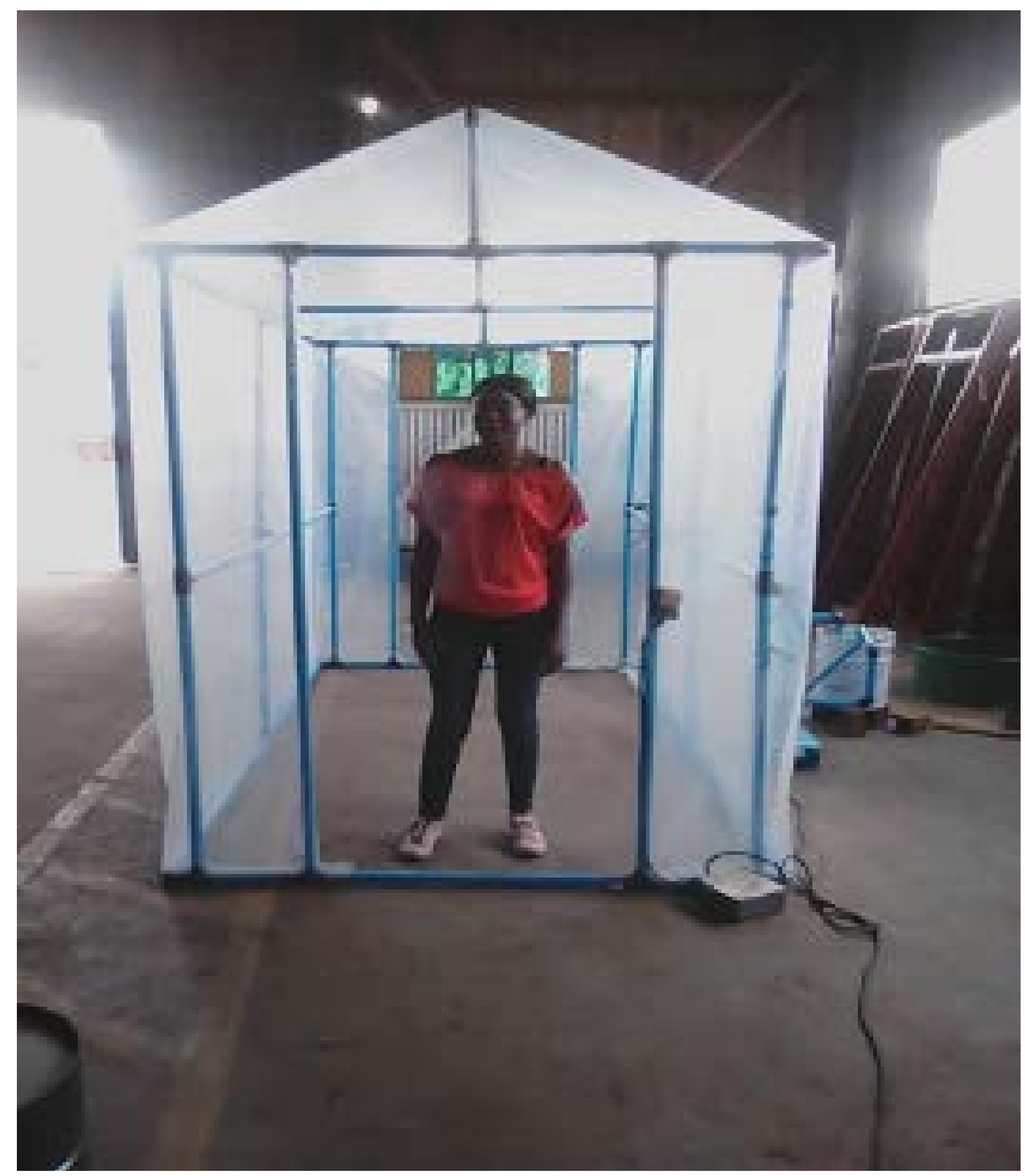

Figure 1. Full-body booth (plastic).

firstly step in the footbath with sanitiser, then move on to wash their hands, followed by sanitisation, before they can touch the borehole handle as a mechanism to help prevent the transmission of the virus.

These innovations can continue to be used beyond the COVID-19 pandemic to wash hands and fight against other infections, such as diarrhoeal diseases including cholera. 
296 Madziva, Thondhlana, Garwe, Murandu, Chagwiza, Chikanza and Maradzika

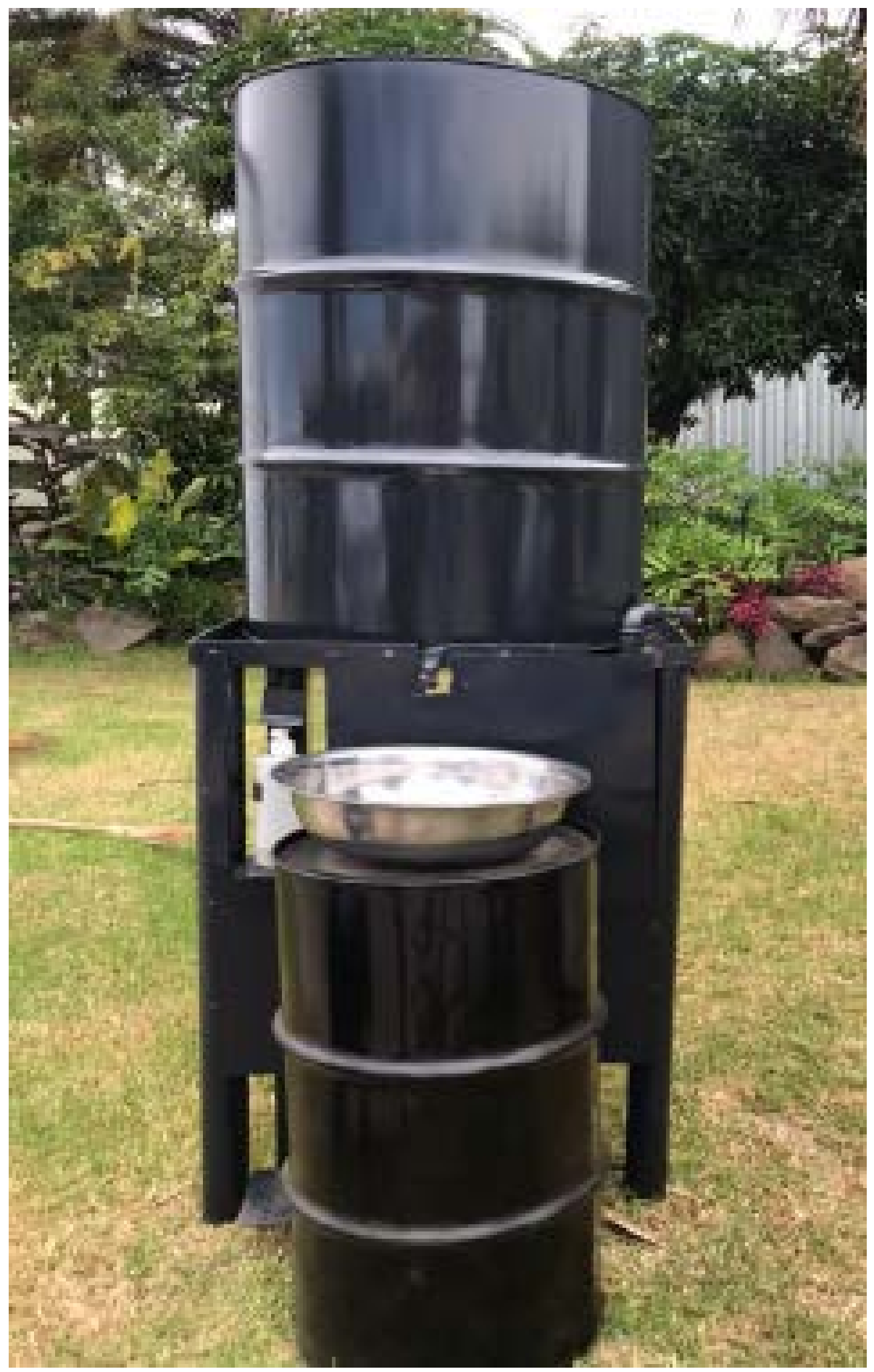

Figure 2. Three in one footbath, handwashing, and sanitising station. 
The whole-body sprayers can continue to be used to prevent the spread of cholera, as it has become endemic in some parts of Zimbabwe, especially in informal settlements. All the innovations are easy to repair and use locally available resources. This is ideal for low-income communities. Importantly, communities can be easily trained on how to maintain the innovations. Batteries which last a year and half are available to power innovations such as the whole-body sanitisers. The batteries are charged using solar energy.

We realise that these innovations require a sustainable supply of sanitisers. To this end, a cheaper sodium-based sanitiser has been developed (and tested for viability) for use in the informal settlements. As part of the project, the next step will be to train the IDP communities to make their own sanitisers, foot-controlled handwashing devices, and detergents/soaps.

\section{Empowering IDPs to produce PPE for use and for income generation}

In addition to supporting our IDP population to fight the pandemic through providing context-relevant COVID-19 public health education messages, and adapting low-cost locally developed COVID-19 protective products, this impact-oriented project sought to empower the community to manage the pandemic beyond the project. This was accomplished through training them so as to enable them to: continue making use of the adapted innovations; make some of the innovative products for use by their households; and start their own income-generation projects, with potential for the economic emancipation of informal settlement dwellers.

To this end, IDPs were trained to produce face masks for home use (and potentially for generating income), particularly the commonly used cloth masks made in accordance with WHO guidelines (WHO 2020b).

\section{Conclusion}

While COVID-19 is a global pandemic, different regions are experiencing the pandemic differently. Zimbabwe, like other African countries, recorded low numbers of COVID19 in the first phase, but has seen a spike in the current and ongoing second phase, which has so far claimed the lives of many people, including four cabinet ministers and several high-ranking officials.

Although the MOHCC, in partnership with local and UN Agencies such as UNICEF, have made information on COVID-19 available to diverse communities, in this article we have tried to show how some of these messages and the related COVID19 preventative measures are not context specific, when we look at the situation of 
IDPs who reside in informal settlements. We have shown how generic messages, such as 'stay at home' and 'maintain social distancing' are almost impossible to abide by, when it comes to IDPs, given their precarious situations. IDPs are individuals who live in abject poverty, with most of them earning less than US\$50 per month, and their precarious situations force them to prioritise securing basics such as income, food, and water, over compliance with COVID-19 regulations. Moreover, some of the messages are difficult for them to understand, as they are not packaged in a way that is accessible for this population.

We have therefore argued for the adaptation of a TPHE that involves co-creation and co-production to enable public health messages to be more accessible for the IDP population. We worked with the IDP population to ensure that key messages are packaged in local language(s), and are delivered through recommended delivery modes, including radio, TV, and community information booths manned by IDP community health promoters.

We have also gone further to discuss the innovations that we adapted as local solutions using locally available cost-effective interventions to enable IDPs to protect themselves from potential viral exposure. As we have also noted, IDPs were trained to make their own PPEs including face masks. We feel that the use of local innovations can help to solve local problems in line with the mantra 'African solutions to African problems'. Such an approach is replicable in similar contexts across Africa and beyond.

Acknowledgements: This work was supported by UKRI's GCRF/Newton Fund Agile Response for COVID-19 [grant number GCRF_NF101].

\section{References}

Black, J. (2014), The Power of Knowledge: How Information and Technology Made the Modern World (Cambridge, MA, Yale University Press). http://www.jstor.org/stable/j.ctt5vm805; https://doi.org/10.12987/yale/9780300167955.001.0001

Chakamba, R. (2021), 'Concerns Mount that a New COVID-19 Variant Could be Spreading in Africa'. https://www.devex.com/news/concerns-mount-that-a-new-COVID-19-variant-could-be-spreadingin-africa- 98881.

Daniels, A. (2020), 'Media Personality Zororo Makamba Becomes First Zimbabwe Coronavirus Fatality',IOL,23March2020.https://www.iol.co.za/news/africa/media-personality-zororo-makambabecomes-first-zimbabwe-coronavirus-fatality-45410008

Deng, F.M. (1999), 'Guiding Principles on Internal Displacement', International Migration Review, 33(2): 484-93. https://doi.org/10.1177/019791839903300209

Facer, K., Lotz-Sisitka, H., Wals, A., Batra, P., McGrath, S., Mitchell, R., Ogbuigwe, A., Tikly, L., Tusiime, M. \& Vogel, C. (2020), The Case for Transformative Public Education: Responding to COVID-19 Now While Addressing Long-term Underlying Inequalities. https://doi.org/10.5281/zenodo.3778587 
Glassman, A., Chalkidou, K. \& Sullivan, R. (2020), 'Does One Size Fit All? Realistic Alternatives for COVID-19 Response in Low-income Countries', 2 April, Centre for Global Development. https://www.cgdev.org/blog/does-one-size-fit-all-realistic-alternatives-covid-19-response-low -income-countries

Hager, S.E. (2007), 'Zimbabwe: Why the United Nations, State, and Non-state Actors Failed to Effectively Regulate Mugabe's Policy of Internal Displacement', California West International Law Journal, 37: $221-76$.

Hammar, A. (2008), 'In the Name of Sovereignty: Displacement and State Making in Post-colonial Independent Zimbabwe', Journal of Contemporary African Studies, 26(4), 417-34. https://doi.org/10.1080/02589000802481999

Hartnack, A. (2005), “"My life got Lost”: Farm Workers and Displacement in Zimbabwe', Journal of Contemporary African Studies, 23(2): 173-92. https://doi.org/10.1080/02589000500176032

Hutchins, S., Fiscella, K., Levine, R., Ompad, D. \& McDonald, M. (2009), 'Protection of Racial/Ethnic Minority Populations During an Influenza Pandemic', American Journal of Public Health, 99(S2): S261-70. https://doi.org/10.2105/AJPH.2009.161505

Juss, S.S. (2013), The Ashgate Research Comparison to Migration Law, Theory and Policy (Aldershot, Ashgate).

Kampala Convention (2009), African Convention for the Protection and Assistance of Internally Displaced Persons in Africa. https://www.unhcr.org/about-us/background/4ae9bede9/african-unionconvention-protection-assistance-internally-displaced-persons.html

Kidia, K.K. (2018), 'The Future of Health in Zimbabwe', Global Health Action, 11(1): article 1496888. https://doi.org/10.1080/16549716.2018.1496888

Mackworth-Young, C.R.S., Chingono, R., Mavodza, C., McHugh, G., Tembo, M., Dziva Chikwari, C., Weiss, H.A., Rusakanika, S., Ruzario, S., Bernays, S. \& Ferrand, R.A. (2020), “"Here, We Cannot Practice What is Preached": Early Qualitative Learning from Community Perspectives on Zimbabwe's Response to COVID-19', Bulletin of the World Health Organization. https://www.who.int/bulletin/online_first/20-260224.pdf

Madziva, R. \& Chikanza, M. (2019), 'Aging While in Transit to Nowhere: The Case Study of Refugees and Migrants Residing in Refugee Camps and Transit Camps in Zimbabwe', scoping project report, University of Nottingham.

Makoni, M. (2021), 'South Africa Responds to New SARS-CoV-2 Variant', Lancet, 397: 267. https://doi.org/10.1016/S0140-6736(21)00144-6

Mutsaka, F. (2021), 'Zimbabwe Holds Burial for 3 Top Leaders who Died of COVID-19', CTV News, 27 January.

Naidu, M. \& Benhura, A. (2014), 'Internal Displacement and Forced Migration Within Zimbabwe: An Overview', Migration and Mobility, 29(2): 147-70.

Refugees International (2020), 'COVID-19 and the Displaced: Addressing the Threat of the Novel Coronavirus in Humanitarian Emergencies', report 30 March 2020. https://www.refugeesinternational .org/reports/2020/3/29/covid-19-and-the-displaced-addressing-the-threat-of-the-novel-coronavirus-inhumanitarian-emergencies

Rodgers, G. (2006), 'Internal Displacement and Social Marginalisation in Southern Africa', Africanus, 36(2): 131-41.

Thieme, T. (2018), 'The hustle Economy: Informality, Uncertainty and the Geographies of Getting By', Progress in Human Geography, 442(4): 529-48. https://doi.org/10.1177/0309132517690039

UNHCR (2011), 'UNHCR Global Appeal 2011 (Update) - Zimbabwe', UNHCR Global Appeal 2011 Update (Geneva, UN High Commissioner for Refugees).

UNHCR (2020a), 'Coronavirus Outbreak' (Geneva, UN High Commissioner for Refugees). https://www.unhcr.org/uk/coronavirus-covid-19.html [accessed 14 August 2020]. 
UNHCR (2020b), The IDP-Initiative, Quarterly Update, June 2020 (Geneva, UN High Commissioner for Refugees). https://reporting.unhcr.org/node/27630

UNHCR (2020c), 'COVID-19: Do Not Forget Internally Displaced Persons, UN Expert Urges Governments Worldwide', news release 1 April (Geneva, UN High Commissioner for Refugees). https://www.ohchr.org/en/NewsEvents/Pages/DisplayNews.aspx?NewsID=25763\&LangID=Ehttps://www.ohchr.org/EN/NewsEvents/Pages/DisplayNews.aspx?NewsID=25763\&LangID=E

Vieira, C.M., Franco, O.H., Restrepo, C.G. \& Abel, T. (2020), 'COVID-19: The Forgotten Priorities of the Pandemic', Maturitas, 136: 38-41. https://doi.org/10.1016/j.maturitas.2020.04.004

WHO (World Health Organization) (2020a), 'WHO Director-General's Opening Remarks at the Media Briefing on COVID-19-11 March 2020' (Geneva, WHO). https://www.who.int/director-general/ speeches/detail/who-director-general-s-opening-remarks-at-the-media-briefing-on-covid-19--11-march-2020

WHO (2020b), 'COVID-19: Operational Guidance for Maintaining Essential Health Services During an Outbreak: Interim Guidance, 25 March 2020' (Geneva, WHO).

ZIMSTAT (2017), Harare Province Population Projection Report, 2017 (Harare, Zimbabwe National Statistics Agency).

\section{Notes on the authors}

Dr Roda Madziva is Assistant Professor in Sociology, at the University of Nottingham. Her research centres around migration and forced displacement, exploring the ideological assumptions that frame discourses of inclusion and exclusion, and the extent to which they reveal hierarchies of human worth. She has published many journal articles and book chapters on migrant and refugee integration.

ORCID ID: https://orcid.org/0000-0003-2485-787x

Roda.Madziva@nottingham.ac.uk

Dr Juliet Thondhlana is Associate Professor in Education and Migration at the University of Nottingham. She researches and publishes on the interaction of language, migration, refugee education, higher education, employability, gender, and entrepreneurship as well as the role of faith. More recently she has conducted research on the internationalisation of higher education in the UK and in Zimbabwe, culminating in the development of a national policy framework for the internationalisation of higher education in Zimbabwe.

ORCID ID: https://orcid.org/0000-0002-4065-5103

juliet.thondhlana@nottingham.ac.uk

Professor Evelyn Chiyevo Garwe is the Deputy Chief Executive Officer for the Zimbabwe Council for Higher Education. She is a keen researcher and practitioner with expertise and experience in quality assurance and strategic and project management. She researches around transformation and quality issues in all aspects of higher 
education including leadership and governance, research, internationalisation, gender, and financing. She is also interested in the ways that inclusive education shapes the narratives regarding various stakeholders for example students, academics, vulnerable societies, etc.

ORCID ID: https://orcid.org/0000-0002-6111-8622

garweec@gmail.com

Dr Moses Murandu holds a Senior Lecturer and Research Enterprise post at the University of Wolverhampton. His research centres on natural health remedies, public health, and innovation. He has researched on the management of wounds using sugar, research which has had worldwide impact and been featured on the BBC and Russian TV as well as various other countries' media.

ORCID ID: https://orcid.org/0000-0001-7776-391X

Mosesmurandu@wlv.ac.uk

Godfrey Chagwiza is a researcher at Zimbabwe Ezekiel Guti University's Centre for Research \& Development. He has interests in optimisation and the application of optimisation techniques to solve real-world problems. Godfrey is also interested in mathematical modelling and resource allocation optimisation.

ORCID ID: https://orcid.org/0000-0002-6343-7125

chagwizag@gmail.com

Marck Chikanza is a social development and management expert specialising in project management, vulnerability and social enterprise management. Marck has worked on and researched vulnerability in agriculture and urban slums. This is in addition to work with old age development and healthy ageing issues where he has an interest in building an understanding of the nexus between ageing and the psychosocial dimensions of health. His research work on ageing covers the following: labour saving agricultural technologies, health, and migration, and culminated in the development and adoption of a Healthy Ageing Strategy by the Zimbabwe government in 2017. mchikanza@ccdsol.org

Dr Julita Chideme Maradzika is a lecturer in Global Public Health at the Faculty of Medicine Health Sciences, University of Zimbabwe. Her research extends from clinical research; health literacy, wellness, patient education, malaria, nutrition, and diarrhoeal diseases to public health aspects such as: health policy, health leadership and governance, inequality in social determinants of health, school health, and sexual 
reproductive health. She has four book publications on HIV: social determinant of health: school health and family coping with terminal illness as well as more than twenty research papers.

ORCID ID: https://orcid.org/0000-0001-8538-9761

jmaradzika@medsch.uz.ac.zw; julimaradzika@gmail.com

To cite the article: Roda Madziva, Juliet Thondhlana, Evelyn Chiyevo Garwe, Moses Murandu, Godfrey Chagwiza, Marck Chikanza and Julita Maradzika (2021), 'Internally displaced persons and COVID-19: a wake-up call for and African solutions to African problems - the case of Zimbabwe', Journal of the British Academy, 9(s1): 285-302.

DOI https://doi.org/10.5871/jba/009s1.285

Journal of the British Academy (ISSN 2052-7217) is published by

The British Academy, 10-11 Carlton House Terrace, London, SW1Y 5AH

www.thebritishacademy.ac.uk 